\title{
Child sacrifice in Uganda: adequacy of existing legal provision
}

\author{
Walakira Eddy ${ }^{1, a}$, Philippa Bogere ${ }^{2, b}$ \\ ${ }^{1}$ Department of Social Work and Social Administration, School of Social Sciences, \\ Makerere University, Kampala, Uganda \\ ${ }^{2}$ School of Law, Makerere University, Kampala, Uganda \\ a,b E-mail address: ewalakira@chuss.mak.ac.ug , philippabogere@gmail.com
}

\begin{abstract}
This article highlights the various incidences of child sacrifice in the country and the legislation in place. It also argues that despite the legislation in place, the incidence of child sacrifice still thrives in Uganda's society due to various factors including failure to enforce the laws in place. The first part examines the situation of child sacrifice currently and the major causes of the practice. The paper examines the legal framework and gaps in the current laws for fighting violence against children. It also contains a brief discussion on how effective the domestic laws are in the current context.
\end{abstract}

Keywords: Child protection; legal provisions; child sacrifice

\section{INTRODUCTION}

\section{1. Child sacrifice in Uganda}

Child sacrifice is a problem that has affected the Ugandan Society for long but did not receive much attention from the relevant authorities until recently. The practice is a challenge in the Ugandan society and is also a serious human rights issue affecting children. There are various human rights issues involved in human sacrifice and these include the right to life, the right to security of a person, physical integrity, personal liberty, freedom from torture or cruel, inhuman or degrading treatment. It also involves abduction and torture of children. ${ }^{1}$ These rights are enshrined in various international instruments to which Uganda is a party. The practice is also a serious criminal offence punishable under the law.

Child sacrifice in Uganda came to the lime light a few years ago after the Police established many were children reported missing, and many were later found dead and with their body organs, that is tongues and private parts missing. Due to re -insurgence of beliefs in African traditional religion and culture, the practice of witchcraft has regained credence and has fuelled the gruesome acts of child sacrifice. While various existing legal initiatives have been enacted to protect children from such practices, implementation is a big challenge due to various factors such as lack of funds, weak enforcement and monitoring mechanisms and ignorance among others. It is also important to note that such legislation mainly focuses

\footnotetext{
${ }^{1} 11^{\text {th }}$ Annual Report of the Uganda Human Rights Commission to the Parliament of the Republic of Uganda, 2008
} 
on child protection and does not specifically focus on the practice of child sacrifice. Basically, there is still a lacunae in describing the criminality and thereby prescribing the appropriate punishment. Many times the accused persons are charged with murder and manslaughter and given lighter sentences that deserved.

According to Commissioner Binoga Moses of the Anti- Human Sacrifice Task Force, according to official police figures, there was one case of child sacrifice in 2006, while in 2008; the police investigated 25 alleged ritual murders and 29 in 2009. According to the 2009 Uganda Police Report on Human Sacrifice, of the 123 persons who went missing in 2009, 90 $(73 \%)$ were children suspected to have become victims of child sacrifice. Further 125 suspects had been arrested at the end of January 2010 and 54 taken to court and charged with various offences such as murder, abductions, kidnap and causing harm and attempting to sell children. In response, the Uganda Police Force set up the Anti- Human Sacrifice Task Force. The Government also enacted the Prevention of Trafficking, In Persons Act in 2009. Further, in February 2009, the government established a 15- member inter-ministerial anti- trafficking task force comprised of police, immigration and Ministry of Gender, Labour and Social Development.

However, it is hard to ascertain the magnitude or the extent of the problem since not all cases are reported to the police. The data available from the Uganda police may not significantly capture the real extent of the problem since many cases are recorded generally and not specifically in relation to child sacrifice. This is further complicated by the fact that sometimes these cases are reported and prosecuted as kidnap or murder as already mentioned above. Further, sometimes these are not prosecuted at all due to lack of sufficient evidence.

\section{2. Brief insight on Child Sacrifice in Uganda}

Child sacrifice may be defined as the killing, mutilation, removal of organs or body parts of a child for sale or for purposes of witchcraft, rituals or any other harmful sacrifice. ${ }^{2}$ The shading of blood as an act of sacrifice and offering is meant to appease certain spirits, remove sin, assuage guilt, win favours, avoid punishment, bond with gods and spirits, avoid conflict, resolve disputes, and celebrate events of family, community or religious significance. ${ }^{3}$ However in the past, sacrifice did not mean shading of human blood but rather that of animals such as chicken, goats and sheep.

The act of child sacrifice has increased significantly over the last decade. Since a big percentage of the population still believe in the power of traditional medicine, traditional healers take advantage of this and manipulate the public. Additionally, there is the belief that child sacrifice is means to wealth, prosperity and success has led to increased cases of child sacrifice. Various factors have been pointed out as fuelling the practice and these include desire for wealth and prosperity, poverty, trickery by traditional healers and inadequate family and community protection. Additionally, the current trends dictate monetization of all services which traditional doctors take advantage of. Child sacrifice may be linked to child trafficking and may be a form of the latter. The Prevention of Trafficking in Persons Act implies that the practice is a form of child trafficking.

\footnotetext{
${ }^{2}$ See section 2 (g) Prevention of Trafficking in Persons Act. The

${ }^{3}$ See Walakira.......
} 


\section{3. Challenges}

The nature of child sacrifice is different from murder but Uganda currently lacks a definition of child sacrifice in the law.

Children and family protection units also lack personnel and infrastructure to effectively do their work.

Currently the judiciary is struggling with the problem of case backlog. There have been efforts to deal with the case backlog through the JLOS Quick Win strategy but there is still a considerable amount of backlog which causes delays and access to justice for those who deserve it. Despite presence of laws on statute books, very few steps have been taken towards the implementation of these legislations by the DPP and the Police. Little effort has also been shown in the prosecuting human trafficking offences and punishing offenders. For instance, the Police received 318 reports of child sacrifice in 2008. Of those involved child stealing and 317 involved child disappearance, child missing or abduction while 18 cases involved murder. Of the 318 cases reported to police, only 29 cases went before the court. The convictions were secured while the majority of the cases 256 were under inquiry and 31 cases had been put away. 154 cases had their status unknown meaning that the children could have been recovered by the parents who never reported back to the police or the children were still missing. ${ }^{4}$ In 2010, 43 suspects were arrested for interrogation out of whom 26 were taken to court and charged with murder, 04 were charged with attempted murder and causing grievous harm for witchcraft purposes. ${ }^{5}$

The Police do not have adequate resources to effectively tackle child sacrifice. There are inadequacies in the investigations processes carried out by the Police due to lack of facilities for forensic evidence like fingerprints which results in low prosecutions. Further, facilitation and logistical support to the Uganda Police Force has led to the delayed follow -up in investigations in relation to human sacrifice.

There is inadequate support from the responsible government authorities regarding implementation of the law. Although the above laws may contain provisions that are relevant for dealing with child trafficking, none of them contains all the necessary provisions required to effectively address the crime.

The civil society is meant to form a link between the government and the public and thus plays a monitoring role in ascertaining if government initiatives are followed up and implemented. However, the civil society in Uganda is still considerably weak and is not yet capable of bringing the government to account.

There are three important government institutions that play an important role in dispensing justice and these include the Judiciary, the Department of Public Prosecution and the Criminal Investigations Department of the Police. However corrupt practices mainly among the junior staff in these institutions have hindered effective service delivery. According to the IGG Report 2010, the Police is considered to be among the most corrupt institutions in Uganda. ${ }^{6}$

There are also problems of general delays in concluding the investigations and prosecution process whereby suspects are released on bail after the mandatory remand period. These suspects at times end up interfering with witnesses.

\footnotetext{
${ }^{4} 11^{\text {th }}$ Annual Report of the Uganda Human Rights Commission to the Parliament of the Republic of Uganda, 2008

${ }^{5}$ Uganda Police Report 2010

${ }^{6}$ According to the IGG report 2002, the police accounted for $10.3 \%$ of the total complaint received. Most complaints included abuse of office, mismanagement and mishandling of cases, bribery and exhortation, delay in service delivery, nonpayment of salaries and other benefits.
} 
The lack of a clear law on the conduct, practice and regulation of traditional healers has made it difficult to identify the genuine ones and to prosecute the criminal ones.

\section{LEGAL FRAMEWORK TO ADDRESS VIOLENCE AGAINST CHILDREN INTERNATIONAL INSTRUMENTS}

Uganda is a party to and has ratified various international instruments to protect children from the violence and other forms of abuse like child sacrifice. However the most relevant include the following.

\section{1. Universal Declaration of Human Rights}

It provides for the right to life, liberty security and personal integrity. It further prohibits torture and cruel, inhuman or degrading punishment or treatment. ${ }^{7}$

\section{2. Convention on the Rights of the Child}

Uganda is party to the Convention of the Rights of the Child which was ratified by the Government in November 1990. It has relevant provisions addressing the problem of child sacrifice in Uganda. As part of the guiding principles and survival rights in the CRC, Article 6 enjoins state parties to recognize that every child has the inherent right to life. Under article 6 (2) state parties have the responsibility to ensure to the maximum extent possible the survival and development of the child. Article 37 provides that no child shall be subjected to torture or other cruel, inhuman or degrading treatment. Various structures have been put in place to implement the CRC. The Department of Children and Youth in the Ministry of Gender, Labour and Social Development is directly responsible for the implementation of the CRC and the protection of Uganda's children. At the lower levels, Local Councils have a secretary for Children's Affairs. Implementation of the Charter especially at lower levels has however faced significant challenges as will be discussed later on.

\section{3. The African Charter on the Rights and Welfare of the Child}

Article 5 (1) stipulates that every child has an inherent right to life which should be protected by law. In addition state parties have to ensure 'to the maximum extent possible ${ }^{8}$ the survival and protection of the child. State parties also have to take specific measures to protect the children from all forms of torture, inhuman or degrading treatment through administrative, social and educational measures. ${ }^{9}$

More specifically countries should take appropriate measures to eliminate harmful social and cultural practices that are prejudicial to the life of the child. ${ }^{10}$ Article 29 prohibits the sale or trafficking of any person. In accordance with article 16 (2) of the Charter, Uganda has put in place some legal frameworks to protect children from torture and inhuman treatment. Article 24 of the Constitution of the Republic of Uganda for instance provides that no person shall be subjected to any form of torture, cruel, inhuman or degrading treatment. The Children Act section 6 also provides for the protection of children from violence and above.

\footnotetext{
${ }^{7}$ Articles 3 and 5

${ }^{8}$ Article 5 (2)

${ }^{9}$ Article 16

${ }^{10}$ Article 21
} 
The Charter was signed by Uganda in February 1992 and later ratified in August 1994. According to a country report ${ }^{11}$, there are still challenges in implementation especially at the lower levels.

\section{4. Protocol to Prevent, Suppress and Punish Trafficking in Persons Especially Women and Children}

Uganda has not ratified the Protocol but it contains some provisions which were the basis and guidelines for the Prevention of Trafficking in Persons. Article 3 of the Protocol defines trafficking in persons to mean 'the recruitment, transportation, transfer, harbouring or receipt of persons by means of the threat or use of force or other forms of coercion, of abduction, of fraud, of deception, of the abuse of power or of a position of vulnerability or of the giving or receiving of payments or benefits to achieve the consent of a person having control over another person, for the purpose of exploitation. Exploitation shall include, at a minimum, the exploitation of the prostitution of others or other forms of sexual exploitation, forced labour or service, slavery or practice similar to slavery, servitude or the removal of organs. Article 3 requires state parties to adopt legislative and other measures necessary to establish criminal offences for the conduct or practices in article 3.

\section{NATIONAL LEGISLATION}

\section{1. The Constitution of the Republic of Uganda, as amended 1995}

The Constitution provides that everyone has an inherent right to life. ${ }^{12}$ The Charter on Rights in the Constitution prohibits any form of torture or cruel, inhuman, degrading treatment. ${ }^{13}$ Under article 17 it is the duty of every citizen to protect children and vulnerable persons against any form of abuse, harassment or ill treatment. Article 34 (1) provides for the rights of children including protection from social or economic exploitation. The Constitution also establishes the Office of the Director of Public Prosecution ${ }^{14}$ whose role among other others to direct the police to investigate any information of a criminal nature and to institute criminal proceedings against any person. ${ }^{15}$

\section{2. The Prevention of Trafficking in Persons Act}

This law was commenced in October 2009 with the specific purpose of preventing and prohibiting trafficking in persons and it successfully incorporates international minimum standards in relation to prohibition and prevention of trafficking. ${ }^{16}$ The act creates specific offences which allow for investigation, prosecution and punishment of offenders. Section 4 of the Act provides for the offence of aggravated trafficking in persons including where the victim of trafficking is a child and this is punishable by life imprisonment. ${ }^{17}$ The same section provides that any person who organises, facilitates or makes preparations for the kidnapping,

\footnotetext{
${ }^{11}$ Ministry of Gender Labour and Social Development, 'Implementation of the African Charter on the Welfare of the Child', November 2007

${ }^{12}$ Article 22

${ }^{13}$ Article 24

${ }^{14}$ Article 34

${ }^{15}$ Article 120

${ }^{16} 2000$ UN Protocol to Prevent, Suppress and Punish Trafficking in Persons Especially Women and Children, and the UN Convention Against Transnational Organised Crime

${ }^{17}$ Section 4 (a)
} 
abduction, buying, selling, vending, bringing from or sending to, receiving, detaining or confining of a person for purposes of harmful rituals or practices, human sacrifice, removal of any body part or organ or any other act related to witchcraft commits aggravated trafficking. ${ }^{18}$ The provisions of section 5 provides for the offence of child trafficking where a person removes any part, organ or tissue from the body of a child for the purposes of human sacrifice. The act also places an obligation on every member of the community to report another person who is suspected of trafficking. ${ }^{19}$

Additionally the minister is required to set up the Prevention of Trafficking in Persons Office for the coordination, monitoring and implementation of the Act. ${ }^{20}$ The functions of the Office include preparing an annual National Plan of Action ${ }^{21}$ and an integrated program ${ }^{22}$ in regard to prevention, prosecution of offenders and protection of (potential) victims. The Office also has the duty to train and raise awareness among government personnel, enforcement officer and the public about trafficking. This office has however not been set up. The minister is also required to make regulation for the implementation of the $\mathrm{Act}^{23}$ but no regulations have been have been made to date. The enactment of this act was an important step towards enforcement of the Act. However, there has been no follow up with the implementation of the provisions of the Act and to date no cases have been prosecuted under the Act. Additionally, there is inadequate support from responsible government authorities to support the implementation of the act.

\section{3. Witchcraft Act Cap 124}

The Act, enacted in 1957 in the colonialist era, was used as an instrument to suppress 'barbaric practices' of the Africans. It was enacted to make provision for the prevention of witchcraft and punishment of persons practicing witchcraft.

Under section 2 (1) of the Witchcraft Act, any person who directly or indirectly threatens another with death by witchcraft or by any other supernatural means commits an offence is liable on conviction to imprisonment for life. However the relevance of the act in today's circumstances and its existence on Uganda's statute books has been questioned especially since there are various legislation. The witchcraft Act does not specifically mention child sacrifice. For instance, the Penal Code Act covering the same offences as those in the Witchcraft Act.

\section{4. The Penal Code Act (as Amended) Cap 120}

The Penal Code Act contains provisions on crimes that are punishable. Section 243 of the Penal Code is clearest law under which an individual may be charged for child sacrifice. The section provides for the offence of kidnapping or detaining with intent to murder.

\section{Kidnapping or detaining with intent to murder}

1) Any person who by force or fraud kidnaps, abducts, takes away or detains, any person against his or her will

\footnotetext{
${ }^{18}$ Section 4 (i)

${ }^{19}$ Section 10

${ }^{20}$ Section 21

${ }^{21}$ Section 21(b)

22 Section 21 (a)

${ }^{23}$ Section 23
} 
a) With intent that such person may be murdered or may be so disposed of as to be put in danger of being murdered;

b) With knowledge that such person will probably be murdered; or

c) With intent to procure a ransom or benefit for the liberation of such person commits an offence and is liable on conviction to suffer death.

2) Where a person so kidnapped or detained is thereafter not seen or heard of within a period of six months or more, the accused person shall be presumed to have had the intentions and knowledge stipulated in subsection (1) (a) and (b).

A considerable number of cases have been instituted in courts of law against individuals accused of child sacrifice including the famous case of Kato Kajubi. However there is no specific provision in the Penal Code Act dealing with someone found in possession of human body parts. Hence this makes it hard to prosecute such a person and to secure a suitable conviction. Other charges that can be preferred against those practicing child sacrifice include kidnapping, abduction

\section{5. Local Government Act Cap 243}

The Local Government Act is the enabling legislation for the decentralization of government administrative structures to allow for the representation and accessible authority in close proximity. This decentralisation has led to the creation of the District Probation and Social Welfare Office and having services closer to the children and their families. Some of the key focus areas for them include monitoring and lobbying for the security of children and ensuring that children stay in environmental conditions that minimize threats to their protection. Local authorities are charged with the duty of protecting the rights and well -being of children in their area of jurisdiction.

The system of governance under the Act presents an opportunity for communities at all levels to participate in decision making. However, there are good practices at national level as compared with the experiences at the district or other lower local governments. The Act under section 25 (4) provides that the Chairperson of a lower local government council is required to assign one of the secretaries to be responsible for the health and children welfare.

Many of the Local Councils at village level have not received any training on the CRC or the Children Act nor have they heard of these legal instruments yet they are the immediate contacts in respect of children in need of care and protection. Additionally local councilors do not have the capacity to screen and assess traditional healers in their area of jurisdiction due to lack of awareness or training.

\section{6. The Children Act Cap 59}

Under Section 5 (2) A parent/ guardian has the duty to protect the child from discrimination, violence, abuse or neglect. Additionally, section 7 of the Act provides that it is unlawful to subject a child to social or customary practices that are harmful to their wellbeing. Part III of the Act provides for Support for Children by Local authorities. Under section 10, it is the duty of the Local Government council right from village to district level to safeguard children. In section 10 (1) (b) a member of the Local Council known as the Secretary for Children's Affairs is to be responsible for the welfare of children. According to a report by the Ministry of Gender, Labour and Social Development (2007) on the 'Implementation of the 
African Charter on the Rights and Welfare of the Child in Uganda', these Secretaries and LCs were trained on children issues by the Ministry of Gender, Labour and Social Development, UNICEF among others. However since political leaders are changed from time to time, this requires continuous training which is not financially viable. Section II 9 of the Children act say the Secretary for Children's Affairs, chosen from the members of the Council is responsible for all matters concerning children. However the above is still far from being regularly and satisfactorily implemented. Protection and welfare officers who are the core personnel for implementing the children act are severely underfunded.

\section{7. Police Act Cap 303}

The Police Act gives a police officer powers to institute criminal proceedings before a magistrate, apply for summons, warrants, search warrants or to undertake any other legal process as may be necessary against a person charged with an offence. ${ }^{24}$

\section{8. Combating Child Sacrifice through law enforcement: What is the way forward?}

Enforcement of the law in relation to child sacrifice is primarily the duty of the Police and the Director of Public Prosecutions. The practice has mainly been prosecuted as kidnapping with intent to murder or as murder. However it may be prosecuted as being in possession of human body parts. However, as already mentioned above the nature of child sacrifice is different from murder and it is therefore necessary to prosecute it under the appropriate law if the country is to keep in line with its international obligations.

\section{CONCLUSION AND RECOMMENDATIONS}

There is need to increase efforts to prosecute, convict and to punish offenders.

Sensitization of community members and local leaders about the issue of child sacrifice and the laws available in place to combat it should be done.

All national laws prohibiting trafficking should be fully enforced.

There is need for close up by the Police of all the outstanding cases and new reports related to human sacrifice.

There is need to set up legislation for distinguishing bona fide herbalists from witch doctors who practice witchcraft and cause a lot of harm including child sacrifice. Many witch doctors do their practice openly under the guise of traditional healers and herbalists since there is no regulatory mechanism. Under this law, the government should set a board or regulatory body to register and regulate the activities the operations of traditional healers and herbalists. This will make it easier to weed out quack herbalists involved in harming children.

The government of Uganda should channel all resources possible for the effective implementation and monitoring of the Trafficking in Persons Act.

There is also need to advocate for increased funding for the anti- human sacrifice task force.

There is need for a comprehensive policy/ strategy to address child sacrifice.

The media in Uganda including newspapers, local/community radio stations, should raise awareness on child sacrifice.

\footnotetext{
${ }^{24}$ Section 31
} 
There is need to develop community based structures for prevention and responses to child sacrifice.

There is also need for capacity building for stakeholders especially community leaders, and the Police among others.

\section{References}

[1] Uganda Human Rights Commission. Annual Report of the Uganda Human Rights Commission to the Parliament of the Republic of Uganda, 2008.

[2] United Nations. Convention on the Rights of the Child. Adopted and opened for signature, ratification and accession by General Assembly resolution 44/25 of 20 November 1989. entry into force 2 September 1990, in accordance with article 49. Available at: http://www.ohchr.org/en/professionalinterest/pages/crc.aspx accessed on December 15, 2013.

[3] Government of Uganda, Inspector General of Government (IGG) Report, 2002.

[4] Government of Uganda, Ministry of Justice and Constitutional Affairs. Local Government Act Cap 243.

[5] Ministry of Gender, Labour and Social Development, 'Implementation of the African Charter on the Rights and Welfare of the Child in Uganda', November, 2007

[6] Government of Uganda, Ministry of Justice and Constitutional Affairs. Police Act Cap 303.

[7] Government of Uganda, Ministry of Justice and Constitutional Affairs. Prevention of Trafficking in Persons Act.

[9] Organization of African Unity. The African Charter on the Rights and Welfare of the Child, 1999. Available at https://www.google.com/webhp? sourceid=chromeinstant\&rlz=1C1SNNT enUG432UG432\&ion=1\&espv=2\&ie $=$ UTF-

$8 \# \mathrm{q}=$ The $\% 20$ African $\% \overline{2}$ CCharter\%20on $\% 20$ the $\% 20$ Rights $\% 20$ and $\% 20$ Welfare $\% 20$ of $\% 2$ 0the $\% 20$ Child

[9] Government of Uganda, Ministry of Justice and Constitutional Affairs. The Constitution of the Republic of Uganda, as amended, 1995.

[10] Government of Uganda, Ministry of Justice and Constitutional Affairs. The Children Act Cap 59.

[11] Government of Uganda, Ministry of Justice and Constitutional Affairs. The Penal Code Act (as Amended) Cap 120.

[12] Government of Uganda, Ministry of Justice and Constitutional Affairs. The Prevention of Trafficking in Persons Act.

[13] The UN Protocol to Prevent, Suppress and Punish Trafficking in Persons Especially Women and Children, and the UN Convention against Transnational Organized Crime, 2000 . 
[14] Uganda Police Report, Government of Uganda. Ministry of Internal Affairs, 2010.

[15] United Nations. Universal Declaration of Human Rights. Available at: http://www.youthforhumanrights.org/what-are-human-rights/universal-declaration-ofhuman-rights/articles-1-15.html, accessed on 15 December 2013.

[16] Government of Uganda. Ministry of Justice and Constitutional Affairs. Witcheraft Act Cap 124. 